\title{
ANTIOXIDANT AND PHYSICOCHEMICAL PROPERTIES OF COOKIES CONTAINING RAW AND ROASTED HEMP FLOUR
}

\author{
Nilgün Ertaş ${ }^{\bowtie}$, Mine Aslan \\ Department of Food Engineering, Engineering and Architecture Faculty, Necmettin Erbakan University \\ Koyceğiz Campus, 42050 Konya, Turkey
}

\begin{abstract}
Background. There has been a resurrection of interest in traditionally cultivated hemp seeds as an alternative food ingredient source over the last few years. Hemp seeds are an excellent food source in terms of protein, dietary fiber, omega fatty acids, vitamins and minerals. In this way, hemp flour allows the development of a product with a high nutritional content for human nutrition.

Materials and methods. This study aimed to investigate the effects of using raw and roasted hemp flour instead of wheat flour (0-5-10-15-20\%) in cookies in terms of physical, chemical and sensorial properties. Results. The results showed significant differences $(p<0.05)$ in some chemical and physical properties among cookies. The addition of raw and roasted hemp flour significantly $(p<0.05)$ affected the color parameters of the cookie samples; $L^{*}$ and $b^{*}$ values decreased and $a^{*}$ values increased. The cookie formulation with increased hemp flour (raw or roasted) resulted in an increase in ash, protein, fat, total phenolic content and antioxidant activity values in the cookie samples, and the highest values were observed with a $20 \%$ level. The raw and roasted hemp flour content significantly decreased the hardness and resulted in softer cookies. For sensory evaluation, the cookies supplemented with raw hemp flour up to $20 \%$ and roasted hemp flour up to $15 \%$ were found to be more desirable by the panelists in terms of overall acceptability.

Conclusion. The results showed the effects of the process applied to the seed and the usability of hemp seed in the product formulation. The nutritional values of hemp seed in the cookie samples demonstrated that it can be used as an alternative ingredient in the development of functional foods.
\end{abstract}

Keywords: hemp seed, roasted, raw, cookie, functional food

\section{INTRODUCTION}

Health concerns have increased the demand of consumers for alternative functional foods. This has led the food industry to tend towards alternative functional food markets. Functional foods have gained importance as preventive and protective agents against different health problems, such as obesity, cardiovascular disease and diabetes etc. For functional and nutritional purposes, foods fortified with seeds provide a source of functional ingredients such as antioxidants, tocopherols, carotenoids, phenols, fibers and proteins.
Functional bakery products have a diverse group of cookie varieties containing different properties and ingredients. Cookies, the most popular amongst consumers, have served as good, ready-to-eat products with a good shelf life (Bala et al., 2015; Kaur et al., 2019). Among functional foods, bakery products such as cookies fortified with flaxseeds (Ganorkar and Jain, 2014), sesame seeds (Kumar and Bhardwaj, 2017) and black cumin seeds (Pawase and Veer, 2020) have also been investigated. 
Seeds have an important role in health, providing disease-prevention benefits thanks to their bioactive ingredients. Various processes apply, particularly roasting in order to increase the bioavailability of seeds. Roasting, the most common process, enhances the antioxidant activity of seeds, both degrading some heatsensitive antioxidative components and forming new ingredients with antioxidant activity through the Maillard reaction (Açar et al., 2009; Nicoli et al., 1999).

Hemp seeds contain considerable amounts of protein (about $34 \%$ protein in dry matter comparable to soy bean), (good amounts of the sulfur-containing amino acids methionine and cysteine), carbohydrates, insoluble fiber, minerals (manganese, potassium, iron, zinc and magnesium) and vitamins (A, B1, B2, B3, B6, C and E). It also has an oil content (over 30\%) with substantial amounts of polyunsaturated fatty acids $(80 \%$ polyunsaturated fatty acids, omega- 6 to omega-3 ratio with between $2: 1$ and 3:1 is considered to be optimal for human health) (Callaway, 2004; Korus et al., 2017a; Russo and Reggiani, 2015). Hemp seeds contain a number of bioactive substances such as flavones, polyphenols, albumin and edistin proteins (Norajit et al., 2011; Ruban et al., 2016). Moreover, thanks to their phenolic compounds, hemp seeds are effective in the prevention of common diseases such as cancer, neurodegenerative diseases, gastrointestinal disorders, and others (Bilotto et al., 2013; Ruban et al., 2016). On the other hand, the psychoactive components in hemp seeds cause consumption anxiety in society. However, industrial hemp has a THC (9-tetrahydrocannabinol) concentration of $\leq 0.3 \%$ on a dry weight basis (Mead, 2017), so it has no psychoactive properties.

Keeping in mind the functional and nutritional benefits of hemp seeds, cookies were prepared with different levels of raw and roasted hemp flour, and the physical, chemical and sensory properties of the cookies were evaluated.

\section{MATERIAL AND METHODS}

\section{Materials}

Hemp seed (Cannabis sativa L.) was supplied from the local market in Konya, Turkey. Wheat flour, sugar powder, shortening, skim milk powder, corn syrup, salt, vanilla and baking powder from local markets in Konya were used in this study.

\section{Methods \\ Roasting procedure of hemp. The hemp seeds were roasted in an oven (Vestel SF 8401, Turkey) at $170^{\circ} \mathrm{C}$ for $30 \mathrm{~min}$. Raw and roasted hemp seeds were ground into flour in a laboratory mill (Alveo, AHE.OG.01, Konya, Turkey) and sieved through a $500 \mu \mathrm{m}$ sieve.}

Preparation of cookie samples. Cookies were prepared using wheat flour (100 g), sugar powder (42 g), shortening (40 g), skim milk powder ( $1 \mathrm{~g})$, corn syrup $(1.5 \mathrm{~g})$, baking powder $(3 \mathrm{~g})$, salt $(1.25 \mathrm{~g})$ and water $(10 \mathrm{~mL})$. The cookie samples were formulated as raw hemp flour or wheat flour-roasted hemp flour in the ratio of 100:0 (control), 95:5, 90:10, 85:15 and $80: 20 \mathrm{w} / \mathrm{w}$. All materials in the cookie formulation were mixed together in a Hobart $\mathrm{N}-50$ mixer (Ontario, Canada) for $10 \mathrm{~min}$. The cookie dough was sheeted to a $5 \mathrm{~mm}$ thickness and cut into circular shapes using a $50 \mathrm{~mm}$ diameter cutter. The shaped cookies were baked in oven (Vestel SF 8401 , Turkey) at $170^{\circ} \mathrm{C}$ for $20 \mathrm{~min}$. The baked cookies were cooled and stored at room temperature for further analysis. The cookie samples containing both raw and roasted hemp flour are represented in Figure 1.

Chemical composition of cookies. The chemical composition of the cookie samples was determined following the AACC method (AACC, 2000) for moisture (AACC method 44-12), ash (AACC Approved 08-01.01), protein (AACC Approved 46-12.01) and crude fat (AACC method 30-10.01). Carbohydrate contents and energy values of the cookies were calculated according to the following formulas (Karaağaoğlu etal., 2008):

Carbohydrate, $\%=100-($ moisture, $\%+$ protein, $\%+$ ash, $\%+$ crude fat, $\%$ content of cookies)

Energy, kcal/100 g = 4 (carbohydrate, \% + protein, \% ) +9 (crude fat, $\%)$.

TPC was determined using the Folin-Ciocalteu spectrophotometric method. For extraction of the total phenolic content (TPC) and antioxidant activity analyses, four grams of a sample was put into a test tube and $10 \mathrm{ml}$ of methanol solution (HCl:methanol:deionized water; $1: 80: 10 \mathrm{ml} \mathrm{v} / \mathrm{v}$ ) was added, then the mixture was kept in a shaking water bath for $2 \mathrm{~h}$. The mixture 


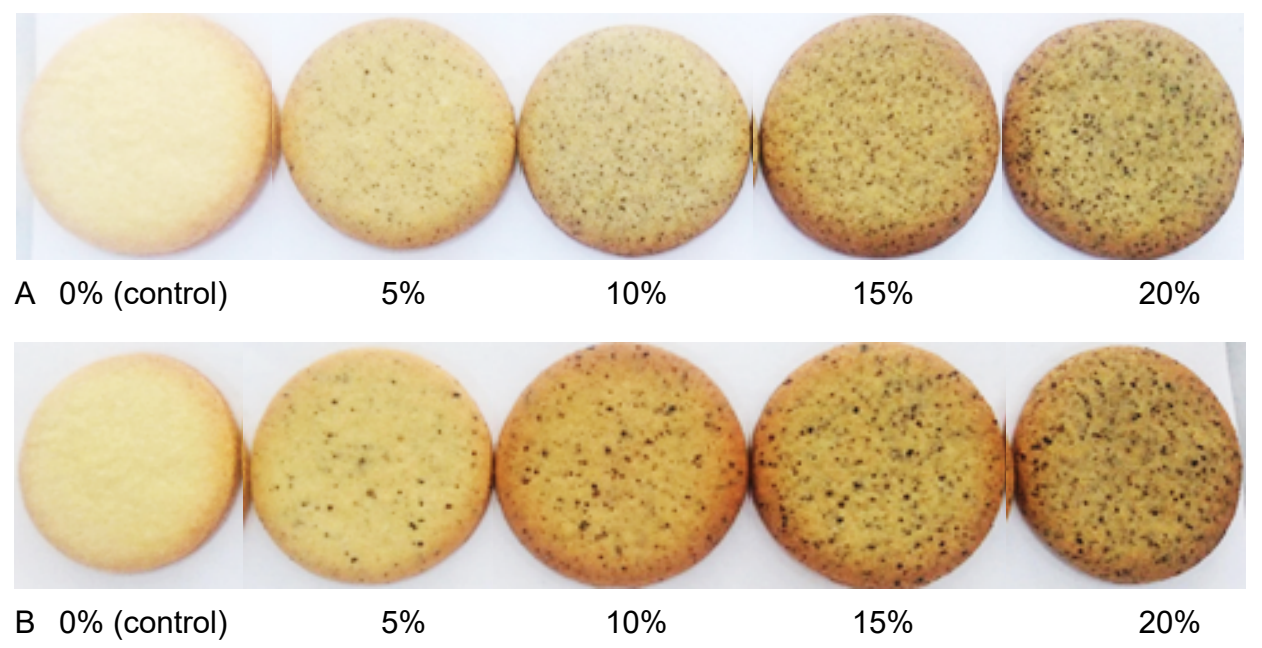

Fig. 1. Cookie samples: A - containing raw hemp flour, B - containing roasted hemp flour

was centrifuged at $3000 \mathrm{rpm}$ for $10 \mathrm{~min}$ and the supernatant was separated. A calibration curve was prepared with different amounts of gallic acid $(100,200,300$, 400 and $500 \mathrm{ppm}$ ) in a methanol solution. The results were expressed as mg GAE/100 g of dry weight (Gao et al., 2002). Antioxidant activity was measured using the DPPH (2-2-diphenyl-2-picrylhydrazyl) method (Beta et al., 2005; Gyamfi et al., 1999). The antioxidant activity value as inhibition percentage was calculated according to Equation 1.

Inhibition, $\%=\left[\left(\mathrm{Abs}_{\text {control }}-\mathrm{Abs}_{\text {sample }}\right) / \mathrm{Abs}_{\text {control }}\right] \times 100$

Physical analyses of cookies. Color measurements of the cookie samples were carried out using a Hunter colorimeter (Minolta Chroma Meter CR-400, Osaka, Japan). Color values of the cookies were recorded as $L^{*}$ (lightness), $a^{*}$ (redness) and $b^{*}$ (yellowness). $a^{*}$ and $b^{*}$ values were used to calculate the chroma (SI) and hue angle $\left(H=\tan ^{-1}\left(b^{*} / a^{*}\right)\right)$ values. The color values were recorded from five different points for each sample.

Measurements of the diameter and thickness values of the cookie samples were evaluated with a digital micrometer $(0.001 \mathrm{~mm}$, Mitutoyo, Minoto-Ku, Tokyo, Japan) at five different places for each cookie and average values were calculated. The diameter values were divided by the thickness values of the cookies and the spread ratio was calculated.
Hardness and fracturability of the cookie samples were measured using a texture analyzer instrument (TA-XT plus, Stable Microsystems, England). After the probe was calibrated, the test was carried out by placing a sample on the table of the texture analyzer. Test conditions were: load cell: $5 \mathrm{~kg}$, pre-test velocity: $0.1 \mathrm{~mm} / \mathrm{s}$, final test velocity: $10.0 \mathrm{~mm} / \mathrm{s}$, distance: $5 \mathrm{~mm}$, trigger force: $50 \mathrm{~g}$.

Sensory analysis. The sensorial properties of the cookie samples were rated for the following parameters: taste, odor, color, fragility, crispness and overall acceptability. The characteristics of the cookie samples were determined by 22 semi-trained panelists. The samples were rated by panelists using a 1-7 scale; 1 - dislike extremely; 7 - the most desirable.

Statistical analysis. All the data were expressed as means \pm standard deviation. The significance of the variations observed among the cookie samples was tested using a software program (JUMP, version 5.0). The average of the main variation sources were compared at $p<0.05$ level.

\section{RESULTS AND DISCUSSION}

Chemical analysis is important in determining the nutritional quality of functional food products. The chemical analysis results of the different cookies 
Ertaş, N., Aslan, M. (2020). Antioxidant and physicochemical properties of cookies containing raw and roasted hemp flour. Acta Sci. Pol. Technol. Aliment., 19(2), 177-184. http://dx.doi.org/10.17306/J.AFS.2020.0795

Table 1. Chemical properties of cookie samples

\begin{tabular}{|c|c|c|c|c|c|c|c|c|c|}
\hline $\begin{array}{l}\text { Additive } \\
\text { type }\end{array}$ & $\begin{array}{c}\text { Additive } \\
\text { ratio } \\
\%\end{array}$ & $\begin{array}{c}\text { Moisture } \\
\%\end{array}$ & $\begin{array}{c}\text { Ash } \\
\%\end{array}$ & $\begin{array}{c}\text { Protein } \\
\%\end{array}$ & $\begin{array}{c}\text { Fat } \\
\%\end{array}$ & $\begin{array}{c}\text { Carbohy- } \\
\text { drate } \\
\%\end{array}$ & $\begin{array}{c}\text { Energy } \\
\text { kcal }\end{array}$ & $\begin{array}{c}\mathrm{TPC}^{2} \\
\mathrm{mg} / \mathrm{GAE} \mathrm{g}\end{array}$ & $\begin{array}{c}\text { Antioxidant } \\
\text { activity } \\
\%\end{array}$ \\
\hline \multirow{5}{*}{$\begin{array}{l}\text { Raw } \\
\text { hemp } \\
\text { flour }\end{array}$} & 0 & $\begin{array}{c}5.04 \\
\pm 0.06^{\mathrm{a}}\end{array}$ & $\begin{array}{c}1.33 \\
\pm 0.04^{\mathrm{d}}\end{array}$ & $\begin{array}{r}8.55 \\
\pm 0.37^{\mathrm{c}}\end{array}$ & $\begin{array}{l}16.26 \\
\pm 0.08^{\mathrm{e}}\end{array}$ & $\begin{array}{l}68.82 \\
\pm 0.55^{\mathrm{ab}}\end{array}$ & $\begin{array}{c}455.82 \\
\pm 0.03^{\mathrm{e}}\end{array}$ & $\begin{array}{r}0.405 \\
\pm 0.06^{\mathrm{d}}\end{array}$ & $\begin{array}{l}33.81 \\
\pm 0.21^{\mathrm{c}}\end{array}$ \\
\hline & 5 & $\begin{array}{c}3.64 \\
\pm 0.03^{\mathrm{b}}\end{array}$ & $\begin{aligned} & 1.58 \\
\pm & 0.01^{\mathrm{c}}\end{aligned}$ & $\begin{array}{c}9.52 \\
\pm 0.57^{\mathrm{bc}}\end{array}$ & $\begin{array}{l}17.16 \\
\pm 0.06^{\mathrm{d}}\end{array}$ & $\begin{array}{l}68.10 \\
\pm 0.66^{\mathrm{a}}\end{array}$ & $\begin{array}{l}464.92 \\
\pm 0.11^{\mathrm{d}}\end{array}$ & $\begin{array}{r}0.559 \\
\pm 0.10^{\text {cd }}\end{array}$ & $\begin{array}{l}34.41 \\
\pm 0.27^{\mathrm{c}}\end{array}$ \\
\hline & 10 & $\begin{array}{c}3.08 \\
\pm 0.08^{\mathrm{c}}\end{array}$ & $\begin{array}{c}1.65 \\
\pm 0.01^{\mathrm{c}}\end{array}$ & $\begin{array}{l}10.40 \\
\pm 0.41^{\mathrm{ab}}\end{array}$ & $\begin{array}{l}17.96 \\
\pm 0.11^{\mathrm{c}}\end{array}$ & $\begin{array}{l}66.91 \\
\pm 0.62^{\mathrm{ab}}\end{array}$ & $\begin{array}{c}470.88 \\
\pm 0.17^{\mathrm{c}}\end{array}$ & $\begin{array}{r}0.813 \\
\pm 0.11^{\mathrm{bc}}\end{array}$ & $\begin{array}{l}36.21 \\
\pm 0.40^{\mathrm{b}}\end{array}$ \\
\hline & 15 & $\begin{array}{c}2.25 \\
\pm 0.07^{\mathrm{d}}\end{array}$ & $\begin{array}{c}1.81 \\
\pm 0.03^{\mathrm{b}}\end{array}$ & $\begin{array}{l}11.03 \\
\pm 0.13^{\mathrm{ab}}\end{array}$ & $\begin{array}{l}18.84 \\
\pm 0.08^{\mathrm{b}}\end{array}$ & $\begin{array}{l}66.07 \\
\pm 0.31^{\mathrm{bc}}\end{array}$ & $\begin{array}{c}477.96 \\
\pm 0.03^{b}\end{array}$ & $\begin{array}{r}1.023 \\
\pm 0.04^{\mathrm{ab}}\end{array}$ & $\begin{array}{l}37.658 \\
\pm 0.19^{\mathrm{a}}\end{array}$ \\
\hline & 20 & $\begin{array}{c}2.15 \\
\pm 0.03^{\mathrm{d}}\end{array}$ & $\begin{array}{c}2.05 \\
\pm 0.06^{\mathrm{a}}\end{array}$ & $\begin{array}{l}11.81 \\
\pm 0.51^{\mathrm{a}}\end{array}$ & $\begin{array}{l}19.39 \\
\pm 0.06^{\mathrm{a}}\end{array}$ & $\begin{array}{l}64.60 \\
\pm 0.65^{\mathrm{c}}\end{array}$ & $\begin{array}{c}480.15 \\
\pm 0.06^{\mathrm{a}}\end{array}$ & $\begin{array}{r}1.222 \\
\pm 0.09^{\mathrm{a}}\end{array}$ & $\begin{array}{l}38.21 \\
\pm 0.23^{\mathrm{a}}\end{array}$ \\
\hline \multirow{5}{*}{$\begin{array}{l}\text { Roasted } \\
\text { hemp } \\
\text { flour }\end{array}$} & 0 & $\begin{array}{c}5.04 \\
\pm 0.07^{\mathrm{a}}\end{array}$ & $\begin{array}{c}1.33 \\
\pm 0.03^{\mathrm{d}}\end{array}$ & $\begin{array}{c}8.55 \\
\pm 0.55^{\mathrm{c}}\end{array}$ & $\begin{array}{l}16.26 \\
\pm 0.04^{\mathrm{e}}\end{array}$ & $\begin{array}{l}68.82 \\
\pm 0.69^{a}\end{array}$ & $\begin{array}{c}455.82 \\
\pm 0.18^{\mathrm{e}}\end{array}$ & $\begin{array}{r}0.405 \\
\pm 0.03^{\mathrm{c}}\end{array}$ & $\begin{array}{l}33.81 \\
\pm 0.22^{\mathrm{d}}\end{array}$ \\
\hline & 5 & $\begin{array}{c}3.21 \\
\pm 0.04^{\mathrm{b}}\end{array}$ & $\begin{array}{c}1.63 \\
\pm 0.04^{\mathrm{c}}\end{array}$ & $\begin{array}{c}9.03 \\
\pm 0.74^{\mathrm{bc}}\end{array}$ & $\begin{array}{l}17.26 \\
\pm 0.10^{\mathrm{d}}\end{array}$ & $\begin{array}{l}68.87 \\
\pm 0.92^{\mathrm{a}}\end{array}$ & $\begin{array}{c}466.94 \\
\pm 0.16^{\mathrm{d}}\end{array}$ & $\begin{array}{r}0.775 \\
\pm 0.04^{\mathrm{b}}\end{array}$ & $\begin{array}{l}35.16 \\
\pm 0.19^{\mathrm{c}}\end{array}$ \\
\hline & 10 & $\begin{array}{c}2.45 \\
\pm 0.08^{\mathrm{c}}\end{array}$ & $\begin{array}{c}1.72 \\
\pm 0.03^{\mathrm{bc}}\end{array}$ & $\begin{array}{c}9.81 \\
\pm 0.38^{\mathrm{abc}}\end{array}$ & $\begin{array}{l}18.22 \\
\pm 0.06^{\mathrm{c}}\end{array}$ & $\begin{array}{l}67.80 \\
\pm 0.55^{\mathrm{ab}}\end{array}$ & $\begin{array}{c}474.42 \\
\pm 0.17^{\mathrm{c}}\end{array}$ & $\begin{array}{r}1.040 \\
\pm 0.12^{\mathrm{b}}\end{array}$ & $\begin{array}{l}37.98 \\
\pm 0.32^{b}\end{array}$ \\
\hline & 15 & $\begin{array}{r}2.25 \\
\pm 0.11^{\mathrm{c}}\end{array}$ & $\begin{array}{c}1.88 \\
\pm 0.04^{\mathrm{b}}\end{array}$ & $\begin{array}{l}10.75 \\
\pm 0.48^{\mathrm{ab}}\end{array}$ & $\begin{array}{l}19.02 \\
\pm 0.08^{\mathrm{b}}\end{array}$ & $\begin{array}{l}66.10 \\
\pm 0.72^{\mathrm{ab}}\end{array}$ & $\begin{array}{c}478.58 \\
\pm 0.20^{b}\end{array}$ & $\begin{array}{r}1.416 \\
\pm 0.10^{\mathrm{a}}\end{array}$ & $\begin{array}{l}38.42 \\
\pm 0.38^{b}\end{array}$ \\
\hline & 20 & $\begin{array}{c}2.09 \\
\pm 0.13^{\mathrm{c}}\end{array}$ & $\begin{array}{c}2.11 \\
\pm 0.06^{\mathrm{a}}\end{array}$ & $\begin{array}{l}11.38 \\
\pm 0.49^{\mathrm{a}}\end{array}$ & $\begin{array}{l}19.56 \\
\pm 0.10^{\mathrm{a}}\end{array}$ & $\begin{array}{l}64.86 \\
\pm 0.78^{\mathrm{b}}\end{array}$ & $\begin{array}{c}481.00 \\
\pm 0.24^{\mathrm{a}}\end{array}$ & $\begin{array}{r}1.634 \\
\pm 0.12^{\mathrm{a}}\end{array}$ & $\begin{array}{l}40.88 \\
\pm 0.18^{\mathrm{a}}\end{array}$ \\
\hline
\end{tabular}

Means followed by the same letter within a column are not significantly different $(p<0.05)$. Chemical properties except moisture are based on dry matter.

TPC - total phenolic content.

samples are represented in Table 1. Replacement of wheat flour with raw (up to $15 \%$ ) and roasted (up to $10 \%$ ) hemp flour in different cookie samples resulted in significant decreases in moisture. Our findings are in accordance with the findings of Kanwal et al. (2015) who observed a decrease in the moisture content with an increased ratio of pumpkin seeds in cookies. The control sample had a lower amount of protein $(8.55 \%)$ and ash $(1.33 \%)$ content, whereas protein and ash content of the other cookie samples increased due to the higher ash and protein contents of raw and roasted hemp flour. The highest ash and protein contents were determined in cookie samples prepared with $20 \%$ roasted hemp flour $(2.11 \%)$ and with $20 \%$ raw hemp flour (11.81), respectively. A $20 \%$ hemp flour addition increased the protein content from 8.55 to $11.81 \%$. A study by Mikulec et al. (2019) reported that use of
$0 \%$ to $50 \%$ hempseed flour in bread samples increased the protein content from $11.02 \%$ to $19.29 \%$.

According to the results, cookies made with $20 \%$ raw hemp flour had $19.39 \%$ fat content and cookies incorporating $20 \%$ roasted hemp flour had $19.56 \%$ fat content. The possible cause of this increase in both can be explained by the higher fat content of hemp flour than wheat flour. These results match those obtained by Lukin and Bitiutskikh (2017) who observed a significant increase in fat values in bread enriched with hemp flour. In terms of carbohydrate content, cookies enriched with $20 \%$ ratio of raw and roasted hemp flour have $64.60 \%$ and $64.86 \%$ values, respectively. Compared to other samples, the control samples had the highest carbohydrate content due to the low fat, protein and ash contents of wheat flour. The addition of raw or roasted hemp flour had a statistically significant effect 
on the energy values of the cookie samples. As the replacement rates of both raw and roasted hemp flour instead of wheat flour increased, the energy values of the cookies increased from 455.82 to $481.00 \mathrm{kcal}$.

The TPC properties of the cookie samples prepared from raw and roasted hemp flour are shown in Table 1. The results indicate that TPC values increase with the addition of raw and roasted hemp flour due to the high TPC content in hemp flour. It was also observed that the TPC values of the cookie samples increased with heat. The highest increase in TPC was observed in the cookie samples containing $20 \%$ roasted hemp flour, which showed a 4.03 fold rise in TPC, while the lowest was recorded for the control cookie sample. Similar results were represented in a previous study conducted by Korus et al. (2017b), who claimed that the use of hemp flour (from 20 to $60 \%$ ) obtained a significant increase $(p<0.05)$ in the TPC content. The inclusion of both raw and roasted hemp flour in the cookie formulation resulted in a significant increase in the antioxidant activity value of the cookies in comparison to the control samples (Table 1). The antioxidant activity contents of cookies containing higher levels of roasted hemp flour $(40.88 \%)$ were found to be higher when compared to cookies prepared from raw hemp flour (38.21\%). These results are compatible with other roasting studies with seeds and it was stated that the product's antioxidant activity increased as a result of the release of phenolic fractions due to heat treatment effects and the formation of new components with antioxidant activity by the Maillard reaction (Carciochi et al., 2016). In another study, Mikulec et al. (2019) stated that the addition of hemp flour openly contributed to enhancing the antioxidant properties of products.

The color properties of the cookie samples containing raw and roasted hemp flour are reported in Table 2. The results showed that there was a significant difference $(p<0.05)$ in color between the cookies made from hemp flour and wheat flour. An increase in raw and roasted hemp flour from 0 to $20 \%$ ratio led to a significant decrease $(P<0.05)$ in the $L^{*}$ values of the cookies. A similar effect on $L^{*}$ values of hemp flour was reported by Zając et al. (2019). Moreover, an increase in $a^{*}$ values and a decrease in $b^{*}$ values were observed as the hemp flour level increased from $0 \%$ to $20 \%$. These results can be explained with the color values of hemp flour. As seen in Table 2, the cookies with the raw hemp flour were significantly darker than the control and, in addition, lower $L^{*}$ values resulted from the cookies containing roasted hemp flour, which were significantly darker than those with raw hemp flour. This finding is in agreement with that reported by Wang et al. (2013) for bread containing hemp flour (from 0 to $40 \%$ ). Cookies with roasted hemp flour were found to have a stronger red and yellow color than the cookies with raw hemp flour. These results

Table 2. Color properties of cookie samples

\begin{tabular}{|c|c|c|c|c|c|c|}
\hline $\begin{array}{l}\text { Additive } \\
\text { type }\end{array}$ & $\begin{array}{c}\text { Additive ratio } \\
\%\end{array}$ & $L^{*}$ & $a^{*}$ & $b^{*}$ & Hue angle & Saturation index \\
\hline \multirow{5}{*}{$\begin{array}{l}\text { Raw hemp } \\
\text { flour }\end{array}$} & 0 & $77.36 \pm 1.73^{\mathrm{a}}$ & $0.46 \pm 0.08^{b}$ & $23.35 \pm 0.81^{\mathrm{a}}$ & $88.87 \pm 1.20^{\mathrm{a}}$ & $23.35 \pm 0.43^{\mathrm{a}}$ \\
\hline & 5 & $72.20 \pm 1.65^{\mathrm{ab}}$ & $0.73 \pm 0.13^{\mathrm{ab}}$ & $21.13 \pm 0.96^{\mathrm{ab}}$ & $88.02 \pm 1.22^{\mathrm{a}}$ & $21.14 \pm 0.12^{\mathrm{b}}$ \\
\hline & 10 & $68.67 \pm 2.29^{\mathrm{b}}$ & $1.09 \pm 0.18^{\mathrm{a}}$ & $19.47 \pm 0.62^{\mathrm{b}}$ & $86.79 \pm 1.10^{\mathrm{a}}$ & $19.50 \pm 0.26^{\mathrm{c}}$ \\
\hline & 15 & $60.24 \pm 1.84^{\mathrm{c}}$ & $1.17 \pm 0.10^{\mathrm{a}}$ & $18.76 \pm 0.33^{\mathrm{b}}$ & $86.43 \pm 1.02^{\mathrm{a}}$ & $18.80 \pm 0.57^{\mathrm{c}}$ \\
\hline & 20 & $56.70 \pm 2.23^{\mathrm{c}}$ & $1.22 \pm 0.16^{\mathrm{a}}$ & $16.01 \pm 0.42^{\mathrm{c}}$ & $85.64 \pm 1.43^{\mathrm{a}}$ & $16.06 \pm 0.31^{\mathrm{d}}$ \\
\hline \multirow{5}{*}{$\begin{array}{l}\text { Roasted } \\
\text { hemp flour }\end{array}$} & 0 & $77.36 \pm 1.37^{\mathrm{a}}$ & $0.46 \pm 0.10^{c}$ & $23.35 \pm 0.33^{\mathrm{a}}$ & $88.87 \pm 1.76^{\mathrm{a}}$ & $23.35 \pm 0.37^{\mathrm{a}}$ \\
\hline & 5 & $72.82 \pm 3.90^{\mathrm{ab}}$ & $0.88 \pm 0.13^{b}$ & $22.03 \pm 0.71^{\mathrm{ab}}$ & $87.71 \pm 1.63^{\mathrm{a}}$ & $22.05 \pm 0.10^{\mathrm{ab}}$ \\
\hline & 10 & $66.81 \pm 6.65^{\mathrm{ab}}$ & $1.05 \pm 0.10^{\mathrm{b}}$ & $21.55 \pm 0.51^{\mathrm{ab}}$ & $87.21 \pm 1.08^{\mathrm{a}}$ & $21.57 \pm 0.55^{\mathrm{b}}$ \\
\hline & 15 & $63.94 \pm 4.09^{\mathrm{ab}}$ & $1.24 \pm 0.07^{\mathrm{ab}}$ & $19.57 \pm 0.65^{\mathrm{bc}}$ & $86.37 \pm 1.45^{\mathrm{a}}$ & $19.61 \pm 0.24^{\mathrm{c}}$ \\
\hline & 20 & $60.60 \pm 0.64^{\mathrm{b}}$ & $1.53 \pm 0.11^{\mathrm{a}}$ & $18.78 \pm 0.92^{\mathrm{c}}$ & $85.34 \pm 1.63^{\mathrm{a}}$ & $18.84 \pm 0.30^{\mathrm{c}}$ \\
\hline
\end{tabular}

Means followed by the same letter within a column are not significantly different $(p<0.05)$. 
can be explained by the various brown pigments formed as a result of the Maillard reaction between reducing sugar and amino acids during the roasting process that can affect the color of the food. The hue angle values of the cookies containing raw and roasted hemp flour were determined as not statistically significant. However, the cookies containing raw hemp flour generally had lower saturation index values than the others. On the other hand, the increased use of hemp flour reduced the share of the saturation index.

Table 3 shows the physical properties of the cookies prepared with different levels of raw and roasted hemp flours. Raw and roasted hemp flour addition caused an increase in the diameter values of the cookies as the level was increased from 0 to $20 \%$. The diameter value of the control cookies was $50.26 \mathrm{~mm}$ while those prepared with $20 \%$ raw hemp flour and $20 \%$ roasted hemp flour were found to be 58.76 and $59.76 \mathrm{~mm}$, respectively. Table 3 indicates that an increase in spread ratio was observed with the incorporation of hemp flour. The spread ratio values of the cookies representing a ratio of diameter to thickness ranged between 7.37 and $10.80 \mathrm{~mm}$. The results showed that replacing wheat flour with untreated and roasted hemp flour caused an important increase in the spread factor of the cookies due to the lack of gluten in hemp seeds. Moreover, Singh et al. (2003) specified that the spread ratio of cookies increased with non-wheat protein content. The high-fat content of hemp seeds may cause an increase in biscuit spread ratio through the action of the fat components, which melt under the influence of heat (Khouryieh and Aramouni, 2012; Pareyt et al., 2009). Also, the spread ratio of cookies can be influenced by the water absorption properties of ingredients, such as flour, during kneading. The increase in the spread ratio of the cookies fortified with hemp flour is in agreement with studies on those enriched with flaxseed flour (Khouryieh and Aramouni, 2012). According to the results, both cookies made with high rates of raw and roasted hemp flour had lower texture values comparable to the control. Hardness values depend on many factors, mainly low gluten content and the gluten network structure formed as a result of the interaction of gluten protein with water molecules (Aslam et al., 2014). The addition of raw and roasted hemp flour to the cookie formulation was determined not to have a significant effect on the fracturabilty properties of the cookies.

The sensory properties of the cookies prepared from raw and roasted hemp flours are shown in Figure 2. With respect to the taste properties of the hemp flour fortified cookies, the lowest value was observed for the control sample while the samples containing hemp flour achieved the highest scores. The taste property scores were determined to be higher in the cookies with $20 \%$ raw hemp flour and $15 \%$ roasted hemp flour

Table 3. Physical properties of cookie samples

\begin{tabular}{lcccccc}
\hline $\begin{array}{c}\text { Additive } \\
\text { type }\end{array}$ & $\begin{array}{c}\text { Additive ratio } \\
\%\end{array}$ & $\begin{array}{c}\text { Diameter } \\
\mathrm{mm}\end{array}$ & $\begin{array}{c}\text { Thickness } \\
\mathrm{mm}\end{array}$ & Spread ratio & $\begin{array}{c}\text { Hardness } \\
\mathrm{N}\end{array}$ & \multicolumn{2}{c}{$\begin{array}{c}\text { Fracturability } \\
\text { mm }\end{array}$} \\
\hline Raw hemp & 0 & $50.26 \pm 0.37^{\mathrm{c}}$ & $6.82 \pm 0.06^{\mathrm{a}}$ & $7.37 \pm 0.17^{\mathrm{e}}$ & $4073.75 \pm 11.48^{\mathrm{a}}$ & $38.04 \pm 0.96^{\mathrm{a}}$ \\
flour & 5 & $51.42 \pm 0.41^{\mathrm{c}}$ & $6.44 \pm 0.16^{\mathrm{ab}}$ & $7.98 \pm 0.13^{\mathrm{d}}$ & $3388.46 \pm 17.68^{\mathrm{b}}$ & $37.67 \pm 0.88^{\mathrm{a}}$ \\
& 10 & $53.84 \pm 0.49^{\mathrm{b}}$ & $6.04 \pm 0.11^{\mathrm{bc}}$ & $8.91 \pm 0.09^{\mathrm{c}}$ & $2400.60 \pm 21.38^{\mathrm{c}}$ & $37.48 \pm 0.68^{\mathrm{a}}$ \\
& 15 & $56.80 \pm 0.68^{\mathrm{a}}$ & $5.74 \pm 0.14^{\mathrm{cd}}$ & $9.89 \pm 0.16^{\mathrm{b}}$ & $1908.36 \pm 11.68^{\mathrm{d}}$ & $36.98 \pm 0.91^{\mathrm{a}}$ \\
& 20 & $58.76 \pm 0.57^{\mathrm{a}}$ & $5.44 \pm 0.06^{\mathrm{d}}$ & $10.80 \pm 0.12^{\mathrm{a}}$ & $1667.52 \pm 28.23^{\mathrm{e}}$ & $36.57 \pm 0.74^{\mathrm{a}}$ \\
\hline Roasted & 0 & $50.26 \pm 0.44^{\mathrm{d}}$ & $6.82 \pm 0.13^{\mathrm{a}}$ & $7.37 \pm 0.14^{\mathrm{c}}$ & $4073.75 \pm 29.67^{\mathrm{a}}$ & $38.04 \pm 0.82^{\mathrm{a}}$ \\
hemp flour & 5 & $52.90 \pm 0.38^{\mathrm{c}}$ & $6.76 \pm 0.10^{\mathrm{a}}$ & $7.82 \pm 0.13^{\mathrm{bc}}$ & $3509.55 \pm 12.53^{\mathrm{b}}$ & $37.53 \pm 0.16^{\mathrm{a}}$ \\
& 10 & $55.76 \pm 0.28^{\mathrm{b}}$ & $6.54 \pm 0.17^{\mathrm{ab}}$ & $8.52 \pm 0.29^{\mathrm{b}}$ & $2529.18 \pm 21.62^{\mathrm{c}}$ & $37.49 \pm 0.14^{\mathrm{a}}$ \\
& 15 & $58.02 \pm 0.65^{\mathrm{a}}$ & $6.14 \pm 0.13^{\mathrm{b}}$ & $9.45 \pm 0.25^{\mathrm{a}}$ & $2198.69 \pm 16.21^{\mathrm{d}}$ & $37.39 \pm 0.47^{\mathrm{a}}$ \\
& 20 & $59.76 \pm 0.42^{\mathrm{a}}$ & $6.08 \pm 0.08^{\mathrm{b}}$ & $9.83 \pm 0.17^{\mathrm{a}}$ & $1881.84 \pm 14.54^{\mathrm{e}}$ & $37.19 \pm 0.30^{\mathrm{a}}$ \\
\hline
\end{tabular}

Means followed by the same letter within a column are not significantly different $(p<0.05)$. 
Ertaş, N., Aslan, M. (2020). Antioxidant and physicochemical properties of cookies containing raw and roasted hemp flour. Acta Sci. Pol. Technol. Aliment., 19(2), 177-184. http://dx.doi.org/10.17306/J.AFS.2020.0795

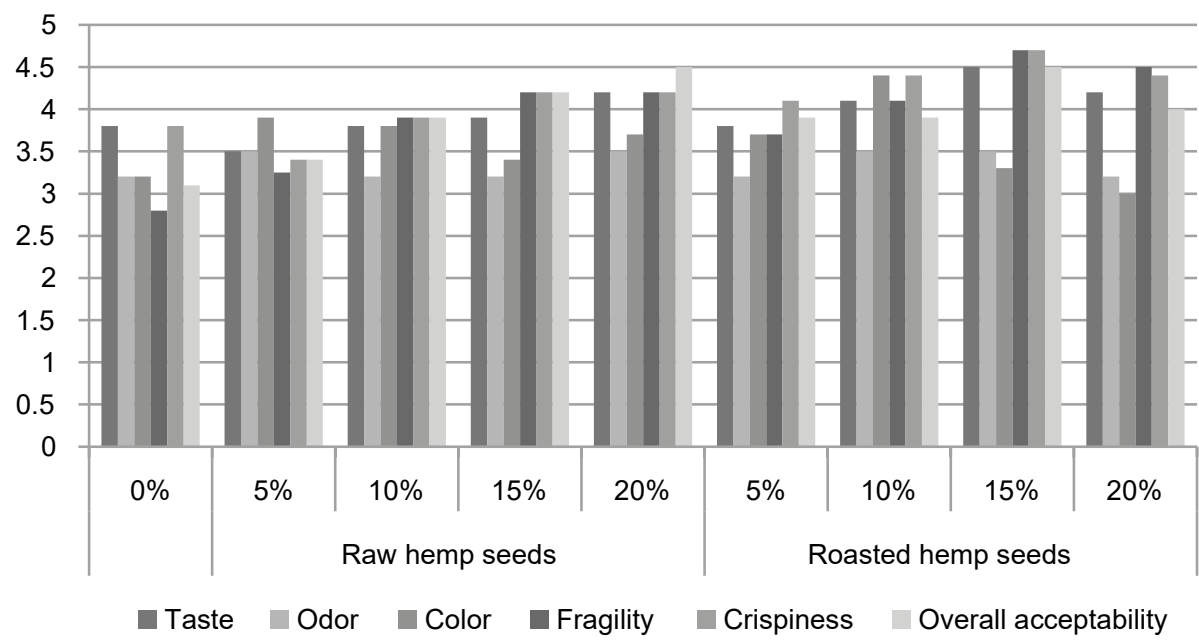

Fig. 2. Sensory properties of cookie samples

than in the others. All levels (0-20\%) of hemp flour in the cookies resulted in similar or higher odor scores compared with the control samples. The highest color scores were observed in the cookie samples fortified with 5\% raw hemp flour and $10 \%$ roasted hemp flour. The fragility score increased with all used proportions and kinds of hemp flour. When evaluating the crispness properties of the cookies, samples with roasted hemp flour received higher scores from the panelists than both the control and the samples containing raw hemp flour. The results of the sensory analysis showed that the cookies containing raw hemp flour up to a level of $20 \%$ and roasted hemp flour up to a level of $15 \%$ resulted in products with good overall acceptability.

\section{CONCLUSION}

The addition effects of raw and roasted hemp flour on the physical, chemical and sensorial qualities of cookies were investigated. The ash, protein and fat of samples containing raw and roasted hemp flour were found to be higher than for control cookies prepared with $100 \%$ wheat flour. Supplementation of $20 \%$ hemp flour enhanced both TPC and antioxidant activity. An increase in the redness of the cookies with the addition of raw and roasted hemp flour was observed. The physical properties of the supplemented cookies showed that, as the level of supplementation increased, the diameter and spread ratio increased, as did the thickness. Using raw hemp flour (up to 20\%) and roasted hemp flour (up to $15 \%$ ) in cookie samples improved their sensory properties in terms of overall acceptability.

\section{REFERENCES}

AACC (2000). Approved methods of the AACC (10th ed.). St. Paul, MN, USA: American Association of Cereal Chemists.

Açar, Ö. Ç., Gökmen, V., Pellegrini, N., Fogliano, V. (2009). Direct evaluation of the total antioxidant capacity of raw and roasted pulses, nuts and seeds. Eur. Food Res. Technol., 229, 6, 961-969.

Aslam, H. K. W., Raheem, M. I. U., Ramzan, R., Shakeel, A., Shoaib, M., Sakandar, H. A. (2014). Utilization of mango waste material (peel, kernel) to enhance dietary fiber content and antioxidant properties of biscuit. J. Glob. Innov. Agric. Soc. Sci., 2, 6-8.

Bala, A., Gul, K., Riar, C. (2015). Functional and sensory properties of cookies prepared from wheat flour supplemented with cassava and water chestnut flours. Cogent Food Agric., 1, 01-07.

Beta, T., Nam, S., Dexter, J. E., Sapirstein, H. D. (2005). Phenolic content and antioxidant activity of pearled wheat and roller-milled fractions. Cereal Chem., 82, 4, 390-393.

Bilotto, S., Spagnuolo, C., Russo, M., Tedesco, I., Laratta, B., Russo, G. L. (2013). Dietary phytochemicals in chemoprevention of cancer: an update. Immunol. Endocr. Metab. Agents Med. Chem., 13, 2-24. 
Callaway, J. C. (2004). Hempseed as a nutritional resource: An overview. Euphytica, 140, 65-72.

Carciochi, R. A., Galván D’Alessandro, L., Manrique, G. D. (2016). Effect of roasting conditions on the antioxidant compounds of quinoa seeds. Int. J. Food Sci. Tech., 51, 4, 1018-1025.

Ganorkar, P. M., Jain, R. K. (2014). Effect of flaxseed incorporation on physical, sensorial, textural and chemical attributes of cookies. Int. Food Res. J., 21, 4, 1515-1521.

Gao, L., Wang, S., Oomah, B. D., Mazza, G. (2002). Wheat quality: Antioxidant activity of wheat millstreams. In P. $\mathrm{Ng}, \mathrm{C} . \mathrm{W}$. Wrigley (Eds.), Wheat quality elucidation (pp. 219-233). St. Paul, MN: AACC International.

Gyamfi, M. A., Yonamine, M., Aniya, Y. (1999). Free-radical scavenging action of medicinal herbs from Ghana: Thonningiasanguinea on experimentally-inducedliverinjuries. General Pharmacol. Vascular Syst., 32, 6, 661-667.

Kanwal, S., Raza, S., Naseem, K., Amjad, M., Bibi, N., Gillani, M. (2015). Development, physico-chemical and sensory properties of biscuits supplemented with pumpkin seeds to combat childhood malnutrition in Pakistan. Pakistan J. Agric. Res., 28, 4.

Karaağaoğlu, N., Karabudak, E., Yavuz, S., Yüksek, O., Dinçer, D., ..., Eren, H. F. (2008). Protein, fat, moisture, carbohydrate and energy values of different types of bread. Gida, 33, 1, 19-25.

Kaur, P., Sharma, P., Kumar, V., Panghal, A., Kaur, J., Gat, Y. (2019). Effect of addition of flaxseed flour on phytochemical, physicochemical, nutritional, and textural properties of cookies. J. Saudi Soc. Agric. Sci., 18, 4, 372-377.

Khouryieh, H., Aramouni, F. (2012). Physical and sensory characteristics of cookies prepared with flaxseed flour. J. Sci. Food Agric., 92, 11, 2366-2372.

Korus, J., Witczak, M., Ziobro, R., Juszczak, L. (2017a). Hemp (Cannabis sativa subsp. sativa) flour and protein preparation as natural nutrients and structure forming agents in starch based gluten-free bread. LWT - Food Sci. Technol., 84, 143-150.

Korus, A., Gumul, D., Krystyjan, M., Juszczak, L., Korus, J. (2017b). Evaluation of the quality, nutritional value and antioxidant activity of gluten-free biscuits made from corn-acorn flour or corn-hemp flour composites. Eur. Food Res. Technol., 243, 8, 1429-1438.

Kumar, M., Bhardwaj, A. (2017). Optimization and quality evaluation of the cookies developed from composite dehulled sesame seed flour blend. Int. J. Adv. Sci. Res. Manag., 2, 8.
Lukin, A., Bitiutskikh, K. (2017). On potential use of hemp flour in bread production. Bull. Transilv. Univ. Brasov., For. Wood Ind. Agric. Food Eng. Ser. II, 10(1).

Mead, A. (2017). The legal status of cannabis (marijuana) and cannabidiol (CBD) under US law. Epilep. Behav., 70, 288-291.

Mikulec, A., Kowalski, S., Sabat, R., Skoczylas, Ł., Tabaszewska, M., Wywrocka-Gurgul, A. (2019). Hemp flour as a valuable component for enriching physicochemical and antioxidant properties of wheat bread. LWT - Food Sci. Technol., 102, 164-172.

Nicoli, M. C., Anese, M., Parpinel, M. (1999). Influence of processing on the antioxidant properties of fruit and vegetables. Trends Food Sci. Technol., 10, 94-100.

Norajit, K., Gu, B. J., Ryu, G. H. (2011). Effects of the addition of hemp powder on the physicochemical properties and energy bar qualities of extruded rice. Food Chem., 129, 4, 1919-1925.

Pareyt, B., Talhaoui, F., Kerckhofs, G., Brijs, K., Goesaert, H., ..., Delcour, J. A. (2009). The role of sugar and fat in sugar-snap cookies: Structural and textural properties. J. Food Eng., 90, 400-408.

Pawase, P. A., Veer, S. J. (2020). Utilization of Black cumin seed (Nigella sativa L.) fractions on quality characteristics of cookies. Int. J. Pharm. Life Sci., 1, 1, 16-22.

Ruban, A., Hrivna, L., Kong, J. L. H., Dostálová, Y., Machálková, L., ..., Trojan, V. (2016). The use of hemp and color wheat flour as baking ingredients. In Proceedings of International $\mathrm{PhD}$ Students Conference (pp. 639-644). Mendel University in Brno: Mendelova univerzita v Brně.

Russo, R., Reggiani, R. (2015). Evaluation of protein concentration, amino acid profile and antinutritional ompounds in hempseed meal from dioeciouus and monocieus varieties. Am. J. Plant Sci., 6, 6, 14-22.

Singh, J., Singh, N., Sharma, T. R., Saxena, S. K. (2003). Physicochemical, rheological and cookie making properties of corn and potato flours. Food Chem., 83, 3, 387-393.

Wang, Y. Y., Norajit, K., Kim, M. H., Kim, Y. H., Ryu, G. H. (2013). Influence of extrusion condition and hemp addition on wheat dough and bread properties. Food Sci. Biotechnol., 22, 1, 89-97.

Zając, M., Guzik, P., Kulawik, P., Tkaczewska, J., Florkiewicz, A., Migdał, W. (2019). The quality of pork loaves with the addition of hemp seeds, de-hulled hemp seeds, hemp protein and hemp flour. LWT - Food Sci. Technol., 105, 190-199. 